Acta Universitatis Wratislaviensis No 4052

https://doi.org/10.19195/0524-4544.332.8

\author{
ADAM OBARA \\ ORCID: 0000-0003-0324-816X \\ Uniwersytet Marii Curie-Skłodowskiej w Lublinie \\ adamobara@onet.eu
}

\title{
Prokuratura Sądu Okręgowego w Zamościu w latach 1944-1950. Zagadnienia wybrane
}

\section{Założenia ustrojowe i organizacyjne prokuratury w latach 1944-1950}

Prokuratura i inne organy państwowe powstawały po drugiej wojnie światowej wraz z kształtowaniem się państwowości polskiej. W miarę wyzwalania kraju spod okupacji hitlerowskiej rozpoczynały swoją działalność polskie sądy i urzędy prokuratorskie ${ }^{1}$. Aparat prokuratury na początku Polski Ludowej był odwzorowaniem instytucji prokuratury przedwojennej z uwzględnieniem nowego porządku politycznego, jak również zaistniałych zmian w zakresie czynników społecznych i ekonomicznych. Status organizacyjny i prawny urzędów prokuratorskich w okresie II Rzeczpospolitej funkcjonował w oparciu o Rozporządzenie Prezydenta Rzeczypospolitej z dnia 6 lutego 1928 roku Prawo o ustroju sądów powszechnych ${ }^{2}$.

1 M. Chigryn, A. Zborowski, Organizacja Prokuratury PRL, [w:] Prokuratura PRL w latach 1950-1960, red. I. Druski, Warszawa 1960, s. 29.

2 Dz.U. Nr 12, poz. 93. Zob. S. Włodyka, Organizacja wymiaru sprawiedliwości, Warszawa 1963, s. 213; L. Mazowiecka, Prokuratura w Polsce 1918-2014, Warszawa 2015, s. 90; M. Siewierski, Ustrój Prokuratury PRL, [w:] Prokuratura PRL..., s. 15. 
Polska prokuratura powojenna była do 1950 roku zorganizowana na wzór niemieckiego modelu, zarówno pod względem kompetencji, struktury, jak i podporządkowania ${ }^{3}$.

Działalność prokuratury była oparta na następujących zasadach: jednolitości, centralizmu, hierarchicznego podporządkowania, legalizmu, substytucji i dewolucji. Zasada jednolitości oznaczała, że prokuratura stanowiła jednolitą całość, to jest: przełożony urzędu prokuratorskiego mógł wykonywać wszelkie czynności należące do zakresu działania prokuratury we wszystkich sądach podlegającego mu okręgu lub ich wykonanie zlecać podwładnym, jak również że czynność prokuratora wiązała prokuraturę. Zgodnie z zasadą centralizmu istniał jeden ośrodek nadzorujący i kierujący, którym był minister sprawiedliwości jako prokurator naczelny. Zasada hierarchicznego podporządkowania oznaczała, że prokurator podlegał zwierzchnikom oraz musiał wykonywać ich polecenia, poza jednym wyjątkiem, kiedy na rozprawie mógł odstąpić od polecenia zwierzchnika w razie ujawnienia nowych okoliczności, zmieniających stan faktyczny. Zasada legalizmu oznaczała, że prokurator występował zawsze w obronie prawa i był obowiązany wszcząć postępowanie karne o przestępstwa ścigane $\mathrm{z}$ urzędu ${ }^{4}$. Z zasady jednolitości można wywieść dwie dalsze dotyczące działania prokuratury, to jest — substytucji i dewolucji. Ta pierwsza oznaczała, że prokurator wyższego rzędu mógł zlecić dokonanie prokuratorowi niższego rzędu w zasadzie każdej czynności. Z kolei druga upoważniała przełożonego do przejęcia i bezpośredniego załatwienia każdej czynności należącej do prokuratora podległego ${ }^{5}$.

W oparciu o rozwiązania przyjęte rozporządzeniem prezydenta RP prokuratura była gruntownie powiązana $\mathrm{z}$ sądami, a naczelnym prokuratorem był minister sprawiedliwości ${ }^{6}$. Porządek organizacyjny prokuratury dostosowany był do struktury sądownictwa. Przy Sądzie Najwyższym działali: pierwszy prokurator, prokuratorzy i wiceprokuratorzy Sądu Najwyższego; przy sądach apelacyjnych — prokuratorzy i wiceprokuratorzy apelacyjni, zaś przy sądach okręgowych prokuratorzy, wiceprokuratorzy i podprokuratorzy okręgowi ${ }^{7}$. Minister sprawiedliwości miał także możliwość ustanowienia w poszczególnych sądach grodzkich

3 S. Włodyka, Ustrój organów ochrony prawnej, Warszawa 1968, s. 205. Niemiecki model prokuratury wyróżniał się tym, że była ona w zasadzie wyłącznie organem państwa do ścigania przestępstw. Do jej kompetencji należało postępowanie przygotowawcze w sprawach karnych i funkcja oskarżyciela publicznego. Poza zakresem jej zainteresowania pozostawała faza wykonywania kary. Stosunek pomiędzy prokuraturą a sądownictwem był oparty na zasadzie równorzędności. Model niemiecki przewidywał podporządkowanie prokuratury ministrowi sprawiedliwości. Zob. idem, Organizacja..., s. 224.

${ }^{4}$ H. Zięba-Załucka, Instytucja prokuratury w Polsce, Warszawa 2003, s. 12, za: L. Mazowiecka, op. cit., s. 75.

5 P. Witkowski, Model prokuratury polskiej w okresie międzywojennym, „Przegląd Prawa Konstytucyjnego" 2011, nr 2, s. 230.

6 Artykuł 232 prawo o ustroju sądów powszechnych (dalej: p.u.s.p.).

${ }^{7}$ Artykuł $233 \S 1$ p.u.s.p. 
podprokuratorów okręgowych ${ }^{8}$. Wiceprokuratorów okręgowych i apelacyjnych mianował prezydent RP na wniosek ministra sprawiedliwości. Wszystkich innych zaś - także prezydent na wniosek ministra sprawiedliwości uchwalony przez Radę Ministrów9.

System organizacyjny aparatu prokuratorskiego II Rzeczpospolitej obejmował: Prokuraturę Sądu Najwyższego, siedem prokuratur apelacyjnych, 45 prokuratur sądów okręgowych oraz dziewięć oddziałów zamiejscowych prokuratur sądów okręgowych ${ }^{10}$.

Według stanu na dzień 1 października 1944 roku działały na terenach wyzwolonych trzy prokuratury sądów apelacyjnych — w Lublinie, Warszawie (z siedzibą w Siedlcach) i Krakowie (z siedzibą w Rzeszowie), oraz pięć prokuratur sądów okręgowych — w Lublinie, Zamościu, Białymstoku, Siedlcach i Rzeszowie ${ }^{11}$.

Mimo że bezpośrednio po drugiej wojnie światowej nie znowelizowano ustaw z okresu międzywojennego, to wydawano nowe drakońskie, specjalne akty prawne, najczęściej dekrety ${ }^{12}$, zawierające przepisy karne przewidujące w licznych przypadkach zagrożenie karą śmierci. W uregulowaniach tych miejsce sędziego śledczego zajmował cywilny funkcjonariusz Ministerstwa Bezpieczeństwa Publicznego oraz wojskowe organy bezpieczeństwa. Prokurator, a nie sąd, decydował o zastosowaniu tymczasowego aresztu. $\mathrm{O}$ wyniku sprawy nie przesądzało postępowanie sądowe, tylko przygotowawcze. Wprowadzono nieznane wcześniej środki karne, jak konfiskata mienia, przymusowa praca w obozach pracy, umieszczenie w miejscach odosobnienia na czas nieokreślony. Orzekały specjalne sądy karne oraz wprowadzono represję administracyjną ${ }^{13}$.

Wprowadzone akty prawne, na ogół drakońsko zmieniające zasady i tryb ponoszenia odpowiedzialności karnej, nie pozostawały, jak się okazuje, bez znaczenia w zakresie funkcjonowania instytucji prokuratury i prokuratorów. Wymagały od nich bezwzględnego podporządkowania się nowym regułom. Prokuratura

\footnotetext{
8 Artykuł 238 § 1 p.u.s.p.

9 Artykuł $238 \S 2$ i $\S 3$ p.u.s.p.

${ }^{10}$ M. Siewierski, op. cit., s. 16-17.

11 M. Chigryn, A. Zborowski, op. cit., s. 29.
}

12 Dekret Polskiego Komitetu Wyzwolenia Narodowego z dnia 15 sierpnia 1944 roku o rozwiązaniu policji państwowej (Dz.U. Nr 2, poz. 6), dekret Polskiego Komitetu Wyzwolenia Narodowego z dnia 7 października 1944 roku o Milicji Obywatelskiej (Dz.U. Nr 7, poz. 33); dekret Polskiego Komitetu Wyzwolenia Narodowego z dnia 31 sierpnia 1944 roku o wymiarze kary dla faszystowsko-hitlerowskich zbrodniarzy winnych zabójstw i znęcania się nad ludnością cywilną i jeńcami oraz dla zdrajców Narodu Polskiego (Dz.U. Nr 4, poz. 16); ustawa z dnia 6 maja 1945 roku o wyłączeniu ze społeczeństwa polskiego wrogich elementów (Dz.U. Nr 17, poz. 96); dekret z dnia 16 listopada 1945 roku o przestępstwach szczególnie niebezpiecznych w okresie odbudowy Państwa (Dz.U. Nr 53, poz. 300); dekret z dnia 16 listopada 1945 roku o postępowaniu doraźnym (Dz.U. Nr 53, poz. 301); dekret z dnia 16 listopada 1945 roku o utworzeniu i zakresie działania Komisji Specjalnej do walki z nadużyciami i szkodnictwem gospodarczym (Dz.U. Nr 53, poz. 302). Szerzej zob. L. Mazowiecka, op. cit., s. 91-95.

13 L. Mazowiecka, op. cit., s. 90. 
i prokuratorzy, niezależnie od tego, czy poszerzono ich kompetencje, czy też je ograniczono, stali się bezwolnymi narzędziami represji ${ }^{14}$. Przejawem tego był dekret z dnia 14 marca 1945 roku o zmianie prawa o ustroju sądów powszechnych ${ }^{15}$, w którym sformułowany został obowiązek wierności prokuratorów wobec ustroju i władzy ludowej w miejsce istniejącego — bezstronności ${ }^{16}$.

Nie budzi wątpliwości fakt, że w ten sposób zamierzano realizować cele szybkiego wymiaru sprawiedliwości, o których mówił datowany na 22 lipca 1944 roku manifest PKWN. Formalnie nadal obowiązywały zasady prawa o ustroju sądów powszechnych z 6 lutego 1928 roku, niemniej jednak w nowej rzeczywistości politycznej w głównej mierze chodziło o to, ,aby sprawiedliwa i szybka kara nie ominęła ani jednego przestępcy, ani jednego zdrajcy narodu". Te słowa premiera Rządu Tymczasowego Edwarda Osóbki-Morawskiego, wygłoszone na posiedzeniu krajowej Rady Narodowej 31 grudnia 1944 roku, stanowiące fragment exposé rządu, wytyczały jednoznaczny kierunek działań ${ }^{17}$.

Nowa władza podkreślała, że

prokuratura ma być i jest bojowym organem dyktatury proletariatu do walki z zakusami wroga klasowego, który czyha, by utrudnić budowę socjalizmu w Polsce. Prokurator - koniecznie członek partii komunistycznej — miał ściśle współpracować z komitetem partii, a prokuratury miały być aktywnymi pomocnikami partii w walce o zwycięstwo socjalizmu ${ }^{18}$.

Wobec tego przy tworzeniu — zaraz po zakończeniu drugiej wojny światowej, a nawet jeszcze w trakcie jej trwania - polskich organów wymiaru sprawiedliwości na pierwsze miejsce wysunął się problem właściwej obsady stanowisk sędziowskich i prokuratorskich. Trudność tego problemu wynikała nie tylko z faktu, że - jak zresztą we wszystkich prawie zawodach — przerzedzone zostały przez wojnę kadry fachowców. Główną komplikację stanowiła okoliczność, że wśród osób, które w okresie międzywojennym pełniły funkcje sędziów i prokuratorów, wiele było tak mocno związanych swymi politycznym poglądami i przeszłą działalnością z sanacyjnym reżimem, że nie czuli się oni gotowi do opowiedzenia się po stronie władzy ludowej, ani też władza ludowa nie mogła ich obdarzyć taką miarą zaufania, aby ich zatrudnić w aparacie wymiaru sprawiedliwości ${ }^{19}$.

Na podstawie dekretu KRN z 22 stycznia 1946 roku $^{20}$ stworzono prawne podstawy obsadzania stanowisk w wymiarze sprawiedliwości, $\mathrm{w}$ tym prokuratorskich,

14 Ibidem, s. 95.

15 Dz.U. Nr 9, poz. 46.

16 S. Włodyka, Organizacja..., s. 214.

17 A. Drogoń, Model prokuratury w systemie wladzy publicznej w Polsce w latach 1944-1956, Katowice 2005, Z Dziejów Prawa, cz. 7, Prace Naukowe Uniwersytetu Śląskiego, nr 2357, s. 155.

18 A. Lityński, O prokuraturze, prokuratorze i procedurze (1944-1950) uwag kilka, [w:] Zasady procesu karnego wobec wyzwań wspótczesności. Księga ku czci profesora Stanisława Waltosia, red. J. Czapska, A. Gaberle, A. Światłowski, A. Zoll, Warszawa 2000, s. 150, cyt. za: L. Mazowiecka, op. cit., s. 101.

19 W. Taraszkiewicz, Osobowa obsada Prokuratury PRL, [w:] Prokuratura PRL..., s. 51.

20 Dz.U. Nr 4, poz. 33. 
przez osoby, które nie ukończyły studiów prawniczych, jak też nie wypełniały innych wymogów przewidzianych przepisami okresu wcześniejszego, za to dawały należytą rękojmię wykonywania zawodu minimum prokuratora. Odpowiednich zezwoleń udzielał minister sprawiedliwości, a podstaw jedynie słusznego rozumienia prawa przyszli prokuratorzy (a także sędziowie, notariusze, adwokaci) mieli się uczyć w średnich szkołach prawniczych ${ }^{21}$.

Pierwsze szkoły powstały już w roku 1946. Prowadziło je Ministerstwo Sprawiedliwości. W latach 1946-1953 powstało ich łącznie sześć (w Łodzi, Wrocławiu, Toruniu, Gdańsku, Szczecinie i Zabrzu) ${ }^{22}$.

Absolwentami kursów byli przedstawiciele klasy robotniczo-chłopskiej, którzy przystępując do szkoły, posiadali niejednokrotnie tylko wykształcenie uzyskane w szkole podstawowej. Takie osoby w dużej mierze decydowały o wymiarze sprawiedliwości w ponurej epoce PRL. Komuniści, dokonując obsady instytucji wymiaru sprawiedliwości, kładli znacznie większy nacisk na ilość i zapatrywania ideologiczne kandydatów na stanowiska sędziów i prokuratorów aniżeli na ich przygotowanie merytoryczne ${ }^{23}$.

\section{Kształtowanie się i obsada Prokuratury Sądu Okręgowego w Zamościu}

Po opuszczeniu Zamojszczyzny przez niemieckiego okupanta z inicjatywy miejscowych przedstawicieli władz sądowych i prokuratorskich, jak również władz administracyjnych, sąd okręgowy i grodzki oraz prokuratura podjęly na nowo działalność 1 sierpnia 1944 roku $^{24}$. Zamojska prokuratura nie była tworzona od podstaw, albowiem 23 lutego 1940 roku na polecenie kierownika Wydziału Prawnego przy szefie dystryktu lubelskiego uruchomiona była przez władze okupacyjne Prokuratura Sądu Okręgowego w Zamościu ${ }^{25}$. Jej kierownikiem mianowany został

21 A. Drogoń, op. cit., s. 171.

22 W. Taraszkiewicz, op. cit., s. 52.

23 Średnie szkoły prawnicze prowadziło Ministerstwo Sprawiedliwości, przy czym udział w prowadzeniu niektórych z nich miała - począwszy od 1950 roku — Generalna Prokuratura. Przeprowadzono w nich łącznie 17 kursów trwających od siedmiu do 13 miesięcy, które ukończyły 1024 osoby. O ile jednak pierwsze turnusy w średnich szkołach prawniczych odpowiadały kryteriom, które leżały u podstaw koncepcji ich utworzenia, to kolejnym coraz trudniej było o kontyngent kandydatów, których poziom doświadczenia życiowego i wiek, a także polityczne wyrobienie byłyby w pełni zadawalające. Narastające w tym względzie trudności zadecydowały w końcu o likwidacji w 1953 roku średnich szkół prawniczych. W. Taraszkiewicz, op. cit., s. 52.

${ }^{24}$ Archiwum Państwowe w Zamościu (dalej: APZ), Prokuratura Sądu Okręgowego w Zamościu, teczka 1, Przedstawienie Prokuratora Sądu Okręgowego w Zamościu do Ministra Sprawiedliwości z dnia 23.06.1945 roku, s. 44.

25 Ibidem. 
prokurator Bohdan Czerniak. Po jego odejściu, 31 lipca 1940 roku i podjęciu pracy adwokata kierownikiem mianowano, od 1 sierpnia 1940, S. Stachurskiego, który pełnił obowiązki do 1 marca 1942 roku, kiedy to kierownictwo prokuratury powierzono Leonardowi Wieczorkiewiczowi ${ }^{26}$. W okresie okupacji prokuratura przejawiała niewielką działalność ograniczającą się do dochodzeń w sprawach o charakterze niepolitycznym i przestępstw kryminalnych mniejszej wagi. W takim kształcie funkcjonowała do odejścia okupanta ${ }^{27}$.

Stan osobowy nowo powstałej prokuratury zamojskiej obejmował jedynie prokuratora okręgowego Leonarda Wieczorkiewicza i podprokuratora Tadeusza Chróściewicza $^{28}$. Jednak już 9 września 1944 roku przyjęty został podprokurator Leon Witkowski, a w 1945 - dwaj kolejni: 14 marca 1945 podprokurator Marian Trzepiota, a 28 kwietnia 1945 podprokurator Marian Męczyński ${ }^{29}$. Leonard Wieczorkiewicz pozostawał prokuratorem okręgowym do 12 marca 1945 roku, kiedy to przeniesiono go do Ostrowa Wielkopolskiego na stanowisko kierownika sądu grodzkiego ${ }^{30}$. Pełniącym obowiązki prokuratora okręgowego został Tadeusz Chróściewicz ${ }^{31}$.

W roku 1946 skład osobowy obejmował cztery etaty prokuratorskie, to jest — prokurator Tadeusz Chróściewicz, podprokuratorzy Marian Męczyński, Leon Witkowski, Leon Frankel (od 30 czerwca 1946), oraz dziewięć etatów urzędni$\mathrm{czych}^{32}$.Zarządzeniem prokuratora Sądu Apelacyjnego w Lublinie 2 maja 1947 roku doszło do kolejnej zmiany na stanowisku p.o. prokuratora okręgowego. Dotychczas wykonujący obowiązki Chróściewicz został zastąpiony przez Eugeniusza Sieprawskiego ${ }^{33}$.

W 1947 roku prokuraturze zamojskiej przyznano dodatkowy etat prokuratorski, co było wynikiem przekazania przez Prokuraturę Sądu Specjalnego w Lublinie spraw o odstępstwo od narodowości polskiej i współpracę z Niemcami. Zatem w 1947 roku prokuratura obejmowała pięć etatów prokuratorskich, to jest - pełniącego obowiązki prokuratora okręgowego Eugeniusza Sieprawskiego, podprokuratorów Mariana Męczyńskiego, Hannę Branecką, Leona Frankela,

26 Ibidem.

27 Ibidem.

28 APZ, Prokuratura Sądu Okręgowego w Zamościu, teczka 1, Przedstawienie Prokuratora Sądu Okręgowego w Zamościu do Ministra Sprawiedliwości z dnia 23.06.1945 roku, s. 44.

29 APZ, Prokuratura Sądu Okręgowego w Zamościu, teczka 23, Imienny wykaz prokuratorów, wiceprokuratorów, asesorów i aplikantów. Sprawozdanie za miesiąc luty 1946 rok.

30 APZ, Prokuratura Sądu Okręgowego w Zamościu, teczka 23, Wykaz składu osobowego Prokuratury Sądu Okręgowego w Zamościu.

31 Ibidem.

32 APZ, Prokuratura Sądu Okręgowego w Zamościu, teczka 30, Wykaz sędziów, prokuratorów, asesorów sądowych za III kwartał 1947 roku, s. 73.

33 APZ, Prokuratura Sądu Okręgowego w Zamościu, teczka 68, Protokół z dnia 2.05.1947 roku, s. 13. 
Karola Lewandowskiego oraz trzech asesorów sądowych: Franciszka Kosia, Witolda Wojczewskiego i Romana Wesołowskiego ${ }^{34}$.

Roman Wesołowski był pierwszym zatrudnionym w Prokuraturze Sądu Okręgowego w Zamościu absolwentem kursu prokuratorskiego w Szkole Prawniczej Ministerstwa Sprawiedliwości we Wrocławiu. Przystępując do kursu prokuratorskiego, w zasadzie pozostawał bez wykształcenia i bez pracy, jak wynika ze złożonych przez niego oświadczeń, ukończył cztery klasy gimnazjum technicznego w Warszawie, posiadał natomiast „odpowiednie zapatrywania ideologiczne”, będąc czynnym aktywistą PPR i PZPR. Po ukończeniu, w dniu 21 lutego 1948 roku, kursu prokuratorskiego i zwolnieniu z wymagań ukończenia wyższych studiów prawniczych reskryptem ministra sprawiedliwości został mianowany asesorem sądowym w okręgu Sądu Apelacyjnego w Lublinie przydzielonym do Prokuratury Sądu Okręgowego w Zamościu ${ }^{35}$.

Dodatkowo minister sprawiedliwości delegował 30 sierpnia 1947 roku sędziów Sądu Grodzkiego w Lublinie: Mieczysława Czernego i Aleksego Staszewskiego, do pełnienia obowiązków wiceprokuratorów prokuratury Sądu Okręgowego w Zamościu do 30 listopada 1947 roku. Aparat urzędniczy prokuratury rozrósł się do 12 osób. W latach 1948-1950 obsada w zasadzie nie uległa zmianie, poza mianowaniem w 1949 roku na stanowisko podprokuratora dotychczasowego asesora sądowego Franciszka Kosia ${ }^{36}$.

Eugeniusz Sieprawski pełnił obowiązki prokuratora okręgowego do zmian ustrojowo-organizacyjnych prokuratury wprowadzonych ustawą z dnia 20 lipca 1950 roku o Prokuraturze Rzeczypospolitej Polskiej, w wyniku których Prokuraturę Sądu Okręgowego w Zamościu zastąpiła Prokuratura Powiatowa w Zamościu 37.

\section{Zasięg terytorialny i działalność Prokuratury Sądu Okręgowego w Zamościu}

Prokuratura Sądu Okręgowego w Zamościu pod względem terytorialnym obejmowała cztery powiaty: zamojski, biłgorajski, tomaszowski i hrubieszowski. Liczba ludności w okręgu zamojskiej prokuratury w roku 1946 wynosiła 461174 osoby, natomiast w 1947 spadła do stanu 421 893. W porównaniu do 539549 zamieszkujących okręg w roku 1939 stan ludności uległ radykalnemu

34 APZ, Prokuratura Sadu Okręgowego w Zamościu, teczka 30, Wykaz sędziów, prokuratorów i asesorów sądowych za III kwartał 1947 roku, s. 73.

35 Archiwum Państwowe w Lublinie, Prokurator Sądu Apelacyjnego w Lublinie, spis 1/2002, 1.p. 26, Akta osobowe Prokuratury Sądu Apelacyjnego w Lublinie.

36 APZ, Prokuratura Sądu Okręgowego w Zamościu, teczka 19, Protokoły z konferencji prokuratorskich w dniach 10.12.1949 r. i 25.02.1950 r., s. 88, 100.

37 Dz.U. Nr 38, poz. 346. 
zmniejszeniu. W powiecie zamojskim ubytek ludności (z 156 tysięcy w 1939 do 138 tysięcy w 1947 roku) nastąpił na skutek wyniszczenia przez okupanta ludności żydowskiej, masowych mordów na zamojskiej „Rotundzie” oraz akcji pacyfikacyjnych. Zmniejszenie liczby ludności w powiecie biłgorajskim (z 121 tysięcy w 1939 do 81276 w 1947 roku) było rezultatem wyniszczenia ludności przez Niemców w czasie akcji przesiedleńczych w latach 1943-1944 oraz na skutek wyjazdu na ziemie zachodnie około 16 tysięcy osób w latach 1945-1947. Ponadto z powiatu biłgorajskiego w latach 1944-1945 przesiedlono do ZSRR około 16500 osób wyznania prawosławnego. Zmiany w zaludnieniu powiatu tomaszowskiego (z 121992 w 1939 do 107222 w 1947 roku) nastąpily na skutek wyjazdu ludności ukraińskiej w latach 1945-1946 do ZSRR, natomiast jeśli chodzi o powiat hrubieszowski, to zmiana zaludnienia (z 129957 w 1939 do 95395 w 1947 roku) była następstwem przesiedlenia ludności ukraińskiej do ZSRR i na ziemie zachodnie ${ }^{38}$.

Teren objęty działalnością Prokuratury Sądu Okręgowego w Zamościu w 1944 roku był podzielony na trzy rejony. W listopadzie 1946 roku utworzone zostały dwa kolejne. Rejon I obejmował teren byłych powiatów: zamojskiego i tomaszowskiego, rejon II — obszar byłego powiatu biłgorajskiego, rejon III - były powiat hrubieszowski, rejon IV - sprawy o odstępstwo od narodowości polskiej, a rejon V - sprawy o współpracę z Niemcami. W 1948 roku zorganizowano rejon VI, do którego właściwości należały sprawy karno-skarbowe. Z dniem 1 października 1948 roku dotychczasowe rejony IV i V uległy likwidacji. Sprawy o przestępstwa z dekretów z dnia 31 sierpnia 1944 roku o wymiarze kary dla faszystowsko-hitlerowskich zbrodniarzy i z dnia 28 czerwca 1946 roku za odstępstwo od narodowości były wpisane do rejestrów ds. poszczególnych rejonów według właściwości miejscowej i załatwiane przez prokuratorów rejonowych ${ }^{39}$.

W związku z wprowadzeniem 1 lipca 1949 roku znowelizowanego kodeksu postępowania karnego zaszła również potrzeba opracowania nowego regulaminu prokuratury. Zadania prokuratora sprowadzono do wykrywania i ścigania przestępstw, podejmowania środków mających na celu zapobieganie przestępczości oraz czuwania nad tym, aby wymiar sprawiedliwości był zgodny z prawem Polski Ludowej i odpowiadał wymaganiom represji karnej. Cele te prokurator winien osiągnąć poprzez:

— niezwłoczne działanie w przypadku uzyskania jakąkolwiek drogą wiadomości o popełnieniu przestępstwa;

38 APZ, Prokuratura Sądu Okręgowego w Zamościu, teczka 25, Przedstawienie Prokuratora Sądu Okręgowego w Zamościu do Prokuratora Sądu Apelacyjnego w Lublinie z dnia 11.08.1948 roku, s. 134-135.

39 APZ, Prokuratura Sądu Okręgowego w Zamościu, teczka 25, Przedstawienie Prokuratora Sądu Okręgowego w Zamościu do Prokuratora Sądu Apelacyjnego w Lublinie z dnia 11.08.1948 roku, s. 135-136. 
— utrzymywanie ścisłego kontaktu ze społeczeństwem, współpracy z partiami politycznymi, terenowymi radami narodowymi, w szczególności z komisjami kontroli społecznej;

— ścisłą współpracę z władzami państwowymi, w tym z władzami bezpieczeństwa, Milicji Obywatelskiej, terenowymi jednostkami kontroli państwowej, Komisji Specjalnej, urzędami skarbowymi akcyz i monopolów państwowych, inspektoratami ochrony skarbowej i urzędami celnymi;

- ocenę i wyciąganie właściwych wniosków z obrad terenowych rad narodowych;

— ścisłą współpracę z sądem w zakresie ustalania zasad polityki kryminalnej ${ }^{40}$.

Zakres spraw prowadzonych przez Prokuraturę Sądu Okręgowego w Zamościu w ogromnej mierze uwarunkowany był sytuacją panującą w powojennej Polsce. Były to zatem sprawy masowych mordów ludności polskiej, przez odstępstwa od narodowości polskiej, w dalszej kolejności sprawy o współpracę z Niemcami i przestępstwa pospolite.

Niewątpliwie największym wyzwaniem, jakie stanęło przed Prokuraturą Sądu Okręgowego w Zamościu, było prowadzenie dochodzenia w sprawie masowych morderstw na terenie zamojskiej „Rotundy”. Prokurator sądu okręgowego prowadził dochodzenie na zlecenie Głównej Komisji Badania Zbrodni Niemieckich w Polsce w sprawie masowych morderstw ludności polskiej przez Niemców w latach 1939-1945. Dochodzenie miało na celu ustalenie:

— okoliczności, w jakich dokonywano mordów;

- sposobu ich dokonania;

— ogólnej liczby zamordowanych;

— imion, nazwisk i miejsca zamieszkania pomordowanych;

— imion, nazwisk, stanowisk służbowych, miejsca pochodzenia sprawców oraz zebranie i zabezpieczenie wszelkich obwieszczeń okupanta dotyczących „Rotundy" $"$.

„Rotunda” została zbudowana za czasów Królestwa Polskiego, w latach 1825-1827, jako działobitnia. Otoczona wodą, położona za miastem i odosobniona doskonale spełniała swą rolę, w wyniku czego po odzyskaniu niepodległości władze polskie wykorzystały jej położenie i umieściły w niej prochownię oraz skład amunicji. Jesienią 1939 roku okupant niemiecki uczynił z „Rotundy” miejsce tortur i straceń. Od czerwca 1940 do 21 lipca 1944 roku poniosło w niej śmierć męczeńską przypuszczalnie 50 tysięcy osób, w szczególności byli to obywatele polscy, jeńcy sowieccy oraz Żydzi. Po raz pierwszy „Rotunda” stała się miejscem masowego więzienia 19 czerwca 1940 roku, kiedy to Niemcy przeprowadzili masową akcję aresztowania inteligencji w Zamościu i okolicznych

40 APZ, Prokuratura Sądu Okręgowego w Zamościu, teczka 6, Poufna Instrukcja Tymczasowa, s. 26.

41 APZ, Prokuratura Sądu Okręgowego w Zamościu, teczka 1158, Korespondencja Prokuratora Sądu Okręgowego w Zamościu do Głównej Komisji Badania Zbrodni Niemieckich w Polsce, s. 404. 
wsiach. Z „Rotundy” aresztowanych przewieziono do Lublina, skąd następnie, poza nieliczną częścią, do obozów koncentracyjnych w Oświęcimiu, Oranienburgu i innych ${ }^{42}$.

Od tego czasu masowe aresztowania, potocznie zwane „masówkami”, stały się powszechne. Ich nasilenie uzależnione było od zdarzeń w powiecie i okolicy oraz ogólnej polityki okupanta. W czasie przeprowadzanych pacyfikacji bezbronną ludność zwożono na „Rotundę” i masowo mordowano. $Z$ zachowanych w aktach zeznań świadków rysuje się przerażające, nieludzkie wprost okrucieństwo. Skazańcy zmuszani byli do kopania dołów dla siebie bądź też przygotowania masowych mogił dla ludzi z kolejnych transportów. Kobiety i dzieci rozstrzeliwano. Zdarzały się jednak sytuacje, iż żywe dzieci wrzucano do dołów, oddawano do nich serię strzałów i zasypywano bez uprzedniego sprawdzenia, czy żyją, bądź też, oszczędzając amunicję, grzebano ludzi żywcem. Ciała pomordowanych wrzucane były do dołów nieprzekraczających wymiarów $4 \times 2$ metry, głębokich na pół metra. Straceni układani byli warstwami, przysypywani wapnem niegaszonym i grzebani. Naziści, chcąc zagłuszyć jęki katowanych i krzyki mordowanych, wychodzili na mury „Rotundy” i grali na harmoniach oraz organkach ${ }^{43}$.

Największe nasilenie mordów miało miejsce od maja do czerwca 1944 roku, kiedy to Niemcy przeprowadzili pacyfikację powiatu biłgorajskiego. W tym czasie aresztowanych zwożono w dzień i w nocy i mordowano. W celu szybkiego i sprawnego przeprowadzania egzekucji z Berlina przybył specjalny oddział Wehrmachtu, który już na stałe pozostał w Zamościu44.

Od końca maja 1944 roku Niemcy zaczęli usuwać ślady zbrodni. W tym celu na dziedzińcu „Rotundy” przygotowali „krematorium”. Wykopywali trupy i wrzucali do dołu o średnicy 3,5 metra, głębokiego na pół metra, na przemian warstwami z palami drzew, oblewali smołą i palili. Swąd unosił się nad Zamościem nieustannie do końca lipca 1944 roku. Prochy spalonych wywozili z „Rotundy", wysypywali do rzeki lub dołów, z których uprzednio wykopywali ciała do spalenia. Zbrodniarze nie usunęli jednak wszystkich masowych grobów. Dnia 25 lipca 1944 roku przed wejściem do „Rotundy” i na dziedzińcu odnaleziono miejsce kaźni zamojskiej ludności ${ }^{45}$.

Dnia 13 października 1945 roku z polecenia kierownika Sądu Grodzkiego w Zamościu — sędziego Karola Lewandowskiego, przy udziale zastępcy burmistrza W. Kazaneckiego, przedstawiciela starostwa Bronisława Mackiewicza oraz urzędnika zarządu miejskiego K. Koziełkiewicza — dokonano oględzin „Rotundy”46.

42 APZ, Prokuratura Sądu Okręgowego w Zamościu, teczka 70, Protokół Prokuratora Sądu Okręgowego w Zamościu z dnia 22.09.1945 roku, s. 9.

43 Ibidem, s. 9.

44 Ibidem, s. 10.

45 Ibidem.

46 Ibidem, s. 11. 
Prokuratura zamojska w ramach prowadzonego postępowania zebrała i uporządkowała wszelki materiał dowodowy. Przesłuchano w trybie sądowym przez sędziego śledczego i sądy grodzkie 75 osób oraz wyznaczono za pośrednictwem wszystkich posterunków w powiatach: zamojskim, biłgorajskim, tomaszowskim i hrubieszowskim, 150 osób mogących posiadać istotne dla dochodzenia informacje. W ramach czynności przeprowadzono osiem ekshumacji, podczas których zbadano 266 ofiar oraz ustalono przy pomocy zarządów gmin wykaz pomordowanych na „Rotundzie"47.

Na zlecenie Głównej Komisji Badania Zbrodni Niemieckich w Polsce prokuratura zamojska prowadziła nadto dwa kolejne dochodzenia. Pierwsze z nich dotyczyło masowego wywozu dzieci z Zamojszczyzny. W wyniku przeprowadzonych czynności ustalono, iż dzieci były wysiedlane razem ze swoimi rodzicami do obozu „za drutami”, który mieścił się w Zamościu, przy ulicy Lubelskiej. W obozie odłączano dzieci od rodziców i umieszczano razem ze starcami w kilku barakach. Dzieci przebywały w skrajnie trudnych warunkach, w brudzie, zimnie i głodzie, w wyniku czego umierały z wycieńczenia. Pozostałe przy życiu były przewożone do Garwolina lub Siedlec. W trakcie transportu sprzedawano je również miejscowej ludności polskiej za kilkadziesiąt złotych. Prokuratorzy ustalili, iż proceder ten odbywał się w ramach ogólnych wysiedleń ludności polskiej ${ }^{48}$. Drugie dochodzenie prowadzono w sprawie zbrodni niemieckich w okresie wysiedleń i pacyfikacji Zamojszczyzny ${ }^{49}$.

Dla ludności cywilnej zamieszkującej na terenie prokuratury zamojskiej szczególnie istotne było poczucie bezpieczeństwa, a w ślad za tym — walka z przestępczością pospolitą. Wypadki kradzieży, napadów rabunkowych i zabójstw na tle porachunków osobistych i o podłożu politycznym były na porządku dziennym. W przeważającej mierze przestępstwa te występowały na terenach powiatów: biłgorajskiego, tomaszowskiego i hrubieszowskiego. W znacznej części raporty informujące o tych zbrodniach do prokuratury w ogóle nie docierały, ponieważ albo sami poszkodowani wypadków tych milicji nie zgłaszali w obawie przed dalszymi represjami, albo też, jeżeli prokuratura meldunki otrzymała, to przeprowadzone dochodzenia nie dawały rezultatu. W konsekwencji nie dochodziło do wykrycia sprawców, a sprawy kończyły się umorzeniem. Zbrodnie te uchodziły więc w znacznej większości przypadków bezkarnie, co sprawców jedynie rozzuchwalało ${ }^{50}$.

47 APZ, Prokuratura Sadu Okręgowego, teczka 1158, Korespondencja Prokuratora Sądu Okręgowego w Zamościu do Głównej Komisji Badania Zbrodni Niemców w Polsce, s. 404.

48 Ibidem, s. 405.

49 Ibidem, s. 406.

50 APZ, Prokuratura Sadu Okręgowego w Zamościu, teczka 19, Przedstawienie Prokuratora Sądu Okręgowego w Zamościu do Prokuratora Sądu Apelacyjnego w Lublinie z dnia 13.09.1948 roku, s. 50. 
Powiaty tomaszowski i hrubieszowski są powiatami granicznymi, stąd sytuacja pod względem bezpieczeństwa była tam szczególnie ciężka. Główną plagę stanowiły bandy UPA liczebnie osiągające nawet 150 osób, uzbrojone w broń palną i granaty. W roku 1948 stan bezpieczeństwa, zwłaszcza w powiatach nadgranicznych, uległ poprawie, do czego przyczyniło się w sposób szczególny przeniesienie ludności ukraińskiej na ziemie zachodnie, co zlikwidowało bazy band UPA. Napady bandyckie nadal występowały, ale nie były one dziełem zorganizowanych grup, w wyniku czego na terenie całej prokuratury zamojskiej zmniejszyła się ilość napadów rabunkowych ${ }^{51}$.

Poza ogólną liczbą napadów rabunkowych zmniejszyła się również ilość spraw o przywłaszczenie mienia poukraińskiego, natomiast w zakresie przestępstw karno-skarbowych dało się zauważyć znaczny spadek tych o nielegalne bimbrownictwo, jeżeli natomiast chodziło o sprawy „tytoniowe”, to w dalszym ciągu występowały one $\mathrm{z}$ dużym nasileniem ${ }^{52}$. Tabela 1 opracowana na podstawie wykazu spraw według repetytorium z 24 września 1947 roku przedstawia rodzaj spraw rozpoznawanych przez Prokuraturę Sądu Okręgowego w Zamościu w okresie od 1 stycznia 1945 do 1 października 1947 roku $^{53}$.

Tabela 1. Rodzaj spraw rozpoznawanych przez Prokuraturę Sądu Okręgowego w Zamościu w okresie od 1 stycznia 1945 do 1 października 1947 roku

\begin{tabular}{|l|r|r|c|c|}
\hline \multicolumn{1}{|c|}{ Rodzaj przestępstwa } & 1945 & 1946 & Do 1 października 1947 & Ogółem \\
\hline zabójstwa & 344 & 295 & 133 & 772 \\
\hline napady rabunkowe & 1018 & 1048 & 498 & 2564 \\
\hline kradzieże & 272 & 332 & 250 & 854 \\
\hline nadużycia służbowe & 74 & 102 & 62 & 238 \\
\hline potajemne gorzelnictwo & 245 & 122 & 167 & 534 \\
\hline współpraca z Niemcami & 0 & 0 & 30 & 30 \\
\hline
\end{tabular}

Źródło: opracowanie własne.

Prokuratura zamojska, wykonując swoje czynności, musiała mierzyć się z wieloma trudnościami. W początkowym okresie w sposób szczególnie uciążliwy odczuwano tak niski stopień wyszkolenia milicji, że funkcjonariusze zupełnie nie orientowali się $\mathrm{w}$ treści wydawanych im w związku z prowadzonymi dochodzeniami polecen ${ }^{54}$. Brak elementarnych podstaw w wyszkoleniu milicjantów, niezbędny przecież przy prowadzeniu dochodzeń, powodował, że poszczególne

51 Ibidem, s. 50.

52 Ibidem.

53 APZ, Prokuratura Sądu Okręgowego w Zamościu, teczka 18, Wykaz spraw wg repetytorium z dnia 24.09.1947 roku, s. 82.

54 APZ, Prokuratura Sądu Okręgowego w Zamościu, teczka 1, Przedstawienie Prokuratora Sądu Okręgowego w Zamościu do Ministra Sprawiedliwości z dnia 23.06.1945 roku, s. 44. 
posterunki pozostawały całkowicie bezradne wobec wydawanych zarządzeń, co w konsekwencji skutkowało ich całkowitym bądź częściowym niewykonywaniem. Regułą było przetrzymywanie przez milicję w aresztach gminnych i w więzieniu w Zamościu zatrzymanych całymi miesiącami bez postanowienia sądu. Braki w wyszkoleniu funkcjonariuszy były na tyle poważne, że w przypadku popełnienia przestępstwa poważnego nie potrafili zabezpieczyć dowodów, pomijali przy przesłuchaniu świadków istotnych dla sprawy bądź dokonywali zarekwirowania przedmiotów niemających żadnego związku z prowadzonym dochodzeniem $^{55}$. Ten stan rzeczy powodował, że prokuratorzy musieli w większości przypadków prowadzić dochodzenia osobiście bądź też dokonywać poszczególnych czynności za pośrednictwem sądów grodzkich i sędziego śledczego ${ }^{56}$.

Dodatkową przeszkodą w zwalczaniu przestępczości, oprócz słabego wyszkolenia milicji, było zlikwidowanie w poszczególnych powiatach całego szeregu posterunków na skutek zdemolowania lokali i rozbrojenia milicjantów. Na terenie Komendy Powiatowej w Tomaszowie Lubelskim spośród 18 posterunków normalnie pracowały jedynie te w Krynicach i Tarnawatce. Działalność pozostałych w większym bądź mniejszym stopniu była ograniczona z powodu grasowania band „bulbowców" 57 . Podobnie sytuacja wyglądała na terenie Komendy Powiatowej w Zamościu, gdzie na 15 posterunków jedynie 10 pracowało, natomiast te w Suchowoli, Potoczku, Radecznicy, Krasnobrodzie i Skierbieszowie wobec zdemolowania ich lokali przez bandy nie istniały. Na terenie powiatu biłgorajskiego natomiast z 14 zorganizowanych funkcjonowały tylko posterunki w Biłgoraju, Tarnogrodzie i Księżpolu. Podobnie sytuacja przedstawiała się na terenie powiatu hrubieszowskiego ${ }^{58}$.

Prokuratura Sądu Okręgowego w Zamościu w takim kształcie działała do drugiej połowy 1950 roku, kiedy to weszła w życie ustawa z dnia 20 lipca 1950 roku o Prokuraturze Rzeczypospolitej Polskiej.

\section{Wnioski}

Lata 1944-1950 w Polsce to dynamiczny okres przemian społeczno-politycznych. Z jednej strony, zadania „nowej władzy” musiały się koncentrować na konieczności stabilizacji ekonomicznej i społecznej państwa po drugiej wojnie światowej, z drugiej - na wprowadzaniu i utrwalaniu nowego ustroju państwa: socjalistycznego.

55 Ibidem, s. 45.

56 Ibidem.

57 Ibidem, s. 47; „bulbowiec” — członek oddziałów Tarasa Borowca „Bulby”, nacjonalisty ukraińskiego.

58 Ibidem. 
Instytucja prokuratury, choć teoretycznie działająca w oparciu o unormowania II Rzeczpospolitej (rozporządzenie Prezydenta Rzeczypospolitej z dnia 6 lutego 1928 roku Prawo o ustroju sądów powszechnych), w rzeczywistości była daleka od tych regulacji. W latach 1944-1945 wprowadzono szereg aktów prawnych, które w sposób wymierny wpływały na funkcjonowanie prokuratury i prokuratorów. Aparat prokuratury był postrzegany przez władzę jako gwarant wprowadzenia socjalizmu, a w dalszej perspektywie - jego utrwalenia. Celem urzeczywistnienia takiego stanu rzeczy w sposób szczególny zadbano o właściwą obsadę stanowisk prokuratorskich. Zajmowały je osoby o właściwym zapatrywaniu ideologicznym, dające rękojmie wierności partii komunistycznej i władzy ludowej.

Tego typu działania komunistów doprowadziły do sytuacji, w której uprzedmiotowiono instytucję prokuratury i uczyniono z niej, szczególnie w sprawach o charakterze politycznym, aparat represji podległy służbom bezpieczeństwa publicznego. Potwierdzeniem takiego stanowiska były słowa zastępcy dyrektora X Departamentu Ministerstwa Bezpieczeństwa Publicznego Józefa Światły: „W tajnym sądzie akt oskarżenia wygotowuje UB, a prokurator tylko podpisuje. Bo aparat bezpieczeństwa nigdy nie miał zaufania do prokuratury i wobec tego taka praktyka się utarła"59.

Ten swego rodzaju dualizm trwał do 1950 roku, kiedy to sejm ,w celu ugruntowania praworządności ludowej, ochrony mienia społecznego i ścigania przestępstw tworzy urząd Generalnego Prokuratora"60 i tym samym wprowadza socjalistyczny model prokuratury.

\section{Bibliografia}

\section{Archiwalia}

Archiwum Państwowe w Lublinie, zespół akt: Prokurator Sądu Apelacyjnego w Lublinie, spis 1/2002, 1.p. 26.

Archiwum Państwowe w Zamościu, zespół akt: Prokuratura Sądu Okręgowego w Zamościu, sygn. teczek: 1, 2, 6, 18, 19, 23, 25, 30, 68, 70, 1158.

\section{Akty prawne}

Dekret Polskiego Komitetu Wyzwolenia Narodowego z dnia 15 sierpnia 1944 roku o rozwiązaniu policji państwowej (tak zwanej granatowej policji) (Dz.U. Nr 2, poz. 6).

59 Z. Błażyński, Mówi Józef Światło. Za kulisami bezpieki i partii 1940-1955, Warszawa 2003, s. 238, cyt. za A. Drogoń, op. cit., s. 157.

60 Artykuł 1 ustawy z dnia 20 lipca 1950 roku o Prokuraturze Rzeczypospolitej Polskiej (Dz.U. Nr 38, poz. 346). 
Dekret Polskiego Komitetu Wyzwolenia Narodowego z dnia 31 sierpnia 1944 roku o wymiarze kary dla faszystowsko-hitlerowskich zbrodniarzy winnych zabójstw i znęcania się nad ludnością cywilną i jeńcami oraz dla zdrajców Narodu Polskiego (Dz.U. Nr 4, poz. 16).

Dekret Polskiego Komitetu Wyzwolenia Narodowego z dnia 7 października 1944 roku o Milicji Obywatelskiej (Dz.U. Nr 7, poz. 33).

Dekret z dnia 16 listopada 1945 roku o postępowaniu doraźnym (Dz.U. Nr 53, poz. 301).

Dekret z dnia 16 listopada 1945 roku o przestępstwach szczególnie niebezpiecznych w okresie odbudowy Państwa (Dz.U. Nr 53, poz. 300).

Dekret z dnia 16 listopada 1945 roku o utworzeniu i zakresie działania Komisji Specjalnej do walki z nadużyciami i szkodnictwem gospodarczym (Dz.U. Nr 53, poz. 302).

Dekret z dnia 22 stycznia 1946 roku o wyjątkowym dopuszczaniu do obejmowania stanowisk sędziowskich, prokuratorskich i notarialnych oraz do wpisywania na listę adwokatów (Dz.U. $\mathrm{Nr}$ 4, poz. 33).

Rozporządzenie Prezydenta Rzeczypospolitej z dnia 6 lutego 1928 roku Prawo o ustroju sądów powszechnych (Dz.U. Nr 12, poz. 93).

Ustawa z dnia 6 maja 1945 roku o wyłączeniu ze społeczeństwa polskiego wrogich elementów (Dz.U. Nr 17, poz. 96).

Ustawa z dnia 20 lipca 1950 roku o Prokuraturze Rzeczypospolitej Polskiej (Dz.U. Nr 38, poz. 346).

\section{Literatura}

Błażyński Z., Mówi Józef Światto. Za kulisami bezpieki i partii 1940-1955, Warszawa 2003.

Chigryn M., Zborowski A., Organizacja Prokuratury PRL, [w:] Prokuratura PRL w latach 19501960, red. I. Druski, Warszawa 1960.

Drogoń A., Model prokuratury w systemie władzy publicznej w Polsce w latach 1944-1956, Katowice 2005, „Z Dziejów Prawa”, cz. 7, s. 154-173.

Lityński A., O prokuraturze, prokuratorze i procedurze (1944-1950) uwag kilka, [w:] Zasady procesu karnego wobec wyzwań współczesności. Księga ku czci profesora Stanisława Waltosia, red. J. Czapska, A. Gaberle, A. Światłowski, A. Zoll, Warszawa 2000.

Mazowiecka L., Prokuratura w Polsce 1918-2014, Warszawa 2015.

Siewierski M., Ustrój Prokuratury PRL, [w:] Prokuratura PRL w latach 1950-1960, red. I. Druski, Warszawa 1960.

Taraszkiewicz W., Osobowa obsada Prokuratury PRL, [w:] Prokuratura PRL w latach 1950-1960, red. I. Druski, Warszawa 1960.

Witkowski P., Model prokuratury polskiej w okresie międzywojennym, „Przegląd Prawa Konstytucyjnego" 2011, nr 2, s. 223-239.

Włodyka S., Organizacja wymiaru sprawiedliwości, Warszawa 1963.

Włodyka S., Ustrój organów ochrony prawnej, Warszawa 1968.

Zięba-Załucka H., Instytucja prokuratury w Polsce, Warszawa 2003.

\section{The Prosecutor's Office at the District Court in Zamość in the years 1944-1950: Selected issues}

\section{Summary}

The study is an attempt to present in general terms the institution of the Prosecutor's Office in the years 1944-1950 in the reality of the Polish state revived after the Second World War. On 
account of the fact that Zamość was located in the border strip within newly established borders, special attention is paid to the activity of the Prosecutor's Office at the District Court in Zamość.

The Prosecutor's Office, just like other state authorities, was created after the Second World War along with the formation of a Polish statehood. The system and the competencies of the post-war Prosecutor's Office were based on the legal regulations enforced in the interwar period, i.e. the Decree Law of the President of the Republic of Poland on organisation of common law courts dated $6^{\text {th }}$ February, 1928. A capitalist type of prosecutor's office was established, based on the German model in particular. Although the new authorities did not make any amendments to these regulations in the years 1944-1945, they introduced some legal acts that had an impact on the functioning of the Prosecutor's Office. The prosecutors' obligation of loyalty to the political system and the people's authorities instead of the existing obligation of impartiality was a clear symptom of that. Consequently, the authorities demanded absolute obedience from prosecutors.

The Prosecutor's Office at the District Court in Zamość began its activity on the initiative of the local authorities after the German occupiers left the region on 1 August 1944. In terms of territory, the Prosecutor's Office included four districts: Zamość, Tomaszów Lubelski, Biłgoraj and Hrubieszów. The post-war social and political situation, as well as the immediate proximity of the border had a significant influence on the scope of the cases handled by the Prosecutor's Office. The investigation into the mass murders of Polish people by the Germans in the area of the Zamość "Rotunda" was the greatest challenge for the Prosecutor's Office at the District Court in Zamość.

The Prosecutor's Office functioned until the middle of 1950, when, as a result of system changes, it was replaced by the District Prosecutor's Office in Zamość.

Keywords: prosecutor's office, court, Second World War, Zamość.

\section{Die Staatsanwaltschaft beim Bezirksgericht Zamość in den Jahren 1944-1950. Gewählte Fragen}

\section{Zusammenfassung}

Die Ausarbeitung ist ein Versuch, die Institution der Staatsanwaltschaft in den Jahren 19441950 in den Realien des nach dem Zweiten Weltkrieg wieder entstehenden polnischen Staates zu skizzieren. Da Zamość nach Festlegung der neuen Grenzen in den grenzanliegenden Streifen gelang, wurde die Aufmerksamkeit der Tätigkeit der Staatsanwaltschaft beim Bezirksgericht Zamość geschenkt.

Die Staatsanwaltschaft und andere Staatsorgane entstanden nach dem Zweiten Weltkrieg zusammen mit der Entwicklung des polnischen Staatswesens. Die Vorschriften, die in der Zwischenkriegszeit mit der Verordnung des Präsidenten der Republik Polen kraft Gesetzes — Gesetz über die Struktur der ordentlichen Gerichte vom 6. Februar 1928 eingeführt wurden, bestimmten die Ordnung und die Kompetenzen der Nachkriegsstaatsanwaltschaft. Sie beschlossen einen kapitalistischen Typ der Staatsanwaltschaft mit besonderer Berücksichtigung des deutschen Modells. Obwohl die „neue Gewalt” diese Regelungen nicht novelliert hat, führte sie bereits in den Jahren 1944-1945 neue Rechtsakte ein, die für die Tätigkeit der Staatsanwaltschaft nicht unerheblich blieben. Seinen Ausdruck fand das in der Verpflichtung der Staatsanwälte, der Staatssystemordnung und der Volksherrschaft treu zu bleiben, die die bisher bestehende Unparteilichkeitspflicht ersetzte. Folglich erwartete die Staatsgewalt ein absolutes Gehorsam der Staatsanwälte.

Die Staatsanwaltschaft beim Bezirksgericht Zamość begann ihre Tätigkeit aus Initiative der örtlichen Obrigkeit nachdem der deutsche Besatzer am 1. August 1944 das Gebiet um Zamość verlassen hat. Die territoriale Zuständigkeit der Staatsanwaltschaft erstreckte sich über vier Kreise: 
Zamość, Tomaszów, Biłgoraj und Hrubieszów. Die sozialpolitische Situation der Nachkriegszeit und die unmittelbare Nähe der Grenze hatten wesentlichen Einfluss auf den Umfang der von der Staatsanwaltschaft bearbeiteten Fälle. Die größte Herausforderung, der sich die Staatsanwaltschaft beim Bezirksgericht Zamość zu stellen hatte, war die Ermittlung in Sachen der deutschen Massenmorde an der polnischen Bevölkerung auf dem Gebiet der „Rotunda“ in Zamość.

Die besprochene Staatsanwaltschaft arbeitete bis Mitte des Jahres 1950, als sie infolge von strukturellen Wandlungen von der Kreisstaatsanwaltschaft Zamość ersetzt wurde.

Schlüsselwörter: Staatsanwaltschaft, Gericht, Zweiter Weltkrieg, Zamość. 